\title{
IMPLEMENTASI FORWARD CHAINING UNTUK MENDIAGNOSIS PENYAKIT TANAMAN KOPI
}

\author{
Kadek Dwi Pradnyani Novianti¹, I Made Deddy Karunia Gunawan ${ }^{2}$, Ni Kadek \\ Sukerti ${ }^{3}$ \\ 1,2,3Prodi Sistem Informasi ITB STIKOM Bali, Jalan Raya Puputan No 86 Renon Denpasar 80234 INDONESIA
}

\begin{abstract}
Abstrak
Pengembangan usaha tani kopi khususnya di daerah Kintamani yaitu di Subak Desa Belantih mejadi perhatian besar karena melihat komoditi kopi menjadi komoditi utama yang dihasilkan dari daerah ini. Namun teknik budidaya tanaman kopi Arabika di daerah Kintamani masih kurang memadai sehingga menimbulkan berbagai gangguan pertumbuhan tanaman. Salah satunya adalah penyakit tanaman. Petani tanaman kopi Arabika di daerah Kintamani memiliki sedikit informasi yang berkaitan dengan penyakit tanaman kopi sehingga penanganannya menjadi tidak sesuai. Untuk mengatasi hal ini kemudian dibangunlah sistem pakar yang mengimplementasikan metode forward chaining untuk mendiagnosis penyakit tanaman padi. Sistem dibuat berbasis web dengan basis data MySQL dan PhpMyAdmin. Setelah sistem berhasil diimplementasi maka dilakukan pengujian menggunakan blackbox testing. Hasil pengujian menunjukan bahwa semua fungsi-fungsi yang ada dapat berjalan sesuai dengan yang diharapkan.
\end{abstract}

Kata Kunci:

Sistem Pakar, Penyakit

Tanaman Kopi Arabika, Forward Chaining

\begin{abstract}
The development of coffee farming, especially in kintamani area, namely in Subak Belantih Village is of great concern because it sees coffee commodity as the main commodity produced from this area. However, the cultivation techniques of Arabica coffee plants in kintamani area are still inadequate so as to cause various disruptions of plant growth. One of them is plant disease. Arabica coffee farmers in Kintamani area have little information related to coffee crop diseases so that the handling becomes inappropriate. To overcome this, an expert system was built that implements forward chaining methods to diagnose rice disease. The system is created web-based with MySQL and PhpMyAdmin databases. After the system is successfully implemented, it is tested using blackbox testing. The test results showed that all existing functions could run as expected.
\end{abstract}

\section{PENDAHULUAN}

Indonesia merupakan negara penghasil kopi terbesar di dunia setelah Brazil dan Columbia. Sebagai komoditi unggulan dalam perdagangan Internasional yang mempunyai nilai ekonomis tinggi, sudah selayaknya pengembangan usaha tani kopi ini mendapat perhatian yang besar, mengingat kontribusinya yang besar pada perekonomian nasional. Provinsi Bali merupakan salah satu daerah penghasil kopi di Indonesia dengan jenis kopi Robusta dan kopi Arabika, namun jenis kopi yang paling banyak diusahakan adalah kopi Arabika. Kecamatan Kintamani merupakan daerah dengan wilayah luas areal kopi Arabika tetinggi di Provinsi Bali (Maridelana, Hariyati, \& Kuntadi, 2014). Kecamatan Kintamani terletak pada ketinggian 900-1550 m dengan kemiringan lereng 1-60\%. Berdasarkan ketinggian di kawasan Kintamani, ketinggian tersebut sesuai untuk budidaya kopi Arabika karena memiliki tanah vulkanik etisol dan inceptisol. Ketinggian antara $900 \mathrm{~m}$ sampai dengan $1.550 \mathrm{~m}$ dpl merupakan ketinggian yang ideal karena kebanyakan kopi Arabika berada pada ketinggian $1.100 \mathrm{~m}$ dpl. Perbedaan suhu antara siang dan malam yang berkisaran $15^{\circ} \mathrm{C}$ sampai dengan $25^{\circ} \mathrm{C}$ sepanjang tahun merupakan faktor yang penting bagi tanaman kopi Arabika (Yoga Priantara, Mulyani, \& Satriawan, 2017). 
Subak Abian Belantih merupakan lokasi perkerbunan kopi rakyat yang terletak di Desa Belantih, Kecamatan Kintamani, Kabupaten Bangli. Sebagian besar penduduk berprofesi sebagai petani, hal ini dikarenakan kawasan Kintamani memiliki ketinggian dan suhu yang cocok untuk dijadikan tempat pertanian dan sebagian besar para petani menanam jeruk dan kopi dengan kopi jenis arabika. Rendahnya produktivitas kopi Arabika daerah Kintamani antara lain disebabkan oleh teknik budidaya tanaman yang kurang memadai, sehingga mendorong timbulnya berbagai gangguan pertumbuhan tanaman, faktor-faktor yang mempengaruhi pertumbuhan dan produktivitas kopi Arabika harus diperhatikan. Salah satu faktor yang dapat menggangu pertumbuhan dan produktivitas kopi Arabika adalah adanya penyakit tanaman. Kurangnya informasi yang diketahui oleh para petani mengenai jenis penyakit yang menyerang menyebabkan penanganan penyakit tidak tertangani dengan benar. Sangat diperlukan informasi melalui penyuluhan-penyuluhan yang diberikan dari Dinas Pertanian dan Perkebunan, serta dapat pula dilakukan melalui mediamedia seperti buku-buku, dan internet.

Namun hanya dengan menggunakan informasi tersebut diatas belum cukup. Menurut wawancara dan observasi yang dilakukan dengan para petani pada Subak Abian Belantih, hal ini dikarenakan para petani tidak dapat langsung berkomunikasi dan melakukan diagnosa sendiri berdasarkan gejala atau fakta yang terjadi di lapangan. Dengan pertimbangan tersebut petani membutuhkan sebuah alat bantu yang dapat memberikan informasi mengenai penyakit yang menyerang tanaman kopi Arabika dan memberikan solusi untuk menangani penyakit tersebut. Alat bantu tersebut dapat berupa sebuah aplikasi sistem pakar. Dengan tujuan, aplikasi sistem pakar ini dapat membantu para petani untuk mengetahui jenis penyakit yang sedang menyerang berdasarkan pada gejala-gejala penyakit yang terlihat. Secara umum, sistem pakar adalah sistem yang berusaha mengadopsi pengetahuan manusia ke komputer yang dirancang untuk memodelkan kemampuan menyelesaikan masalah seperti layaknya seorang pakar. Dalam penyusunannya, sistem pakar mengkombinasikan kaidah-kaidah penarikan kesimpulan (Inference Rules) dengan basis pengetahuan tertentu yang diberikan oleh satu atau lebih pakar dalam bidang tertentu. Kombinasi dari kedua hal tersebut disimpan dalam komputer, yang selanjutnya digunakan dalam proses pengambilan keputusan untuk penyelesaian masalah tertentu. Salah satu metode sistem pakar yang dapat digunakan adalah Forward Chaining. Forward Chaining merupakan proses perunutan yang dimulai dengan menampilkan kumpulan data atau fakta yang meyakinkan menuju konklusi akhir. Mencermati hal-hal di atas maka dilakukan penelitian yang mengimplementasikan metode forward chaining untuk pengembangan sistem pakar diagnosis penyakit tanaman kopi arabika di Kintamani.

Beberapa penelitian yang melakukan pengembangan sistem pakar sebagai alat bantu untuk pertanian adalah sebagai berikut. Penelitian yang dilakukan oleh Elkayana U.K Ndurumbawa dengan judul "Sistem Pakar Diagnosa Penyakit Tanaman Kapas menggunakan Metode Decision Tree berbasis Android". Berlangsung di kabupaten Sumba Timur-NTT. Aplikasi Sistem Pakar ini dibangun dengan berbasis android dengan menggunakan metode Decision Tree. Aplikasi Sitem Pakar ini memberikan informasi yang ditampilkan berupa gambar ciri-ciri penyakit tanaman kapas dan hama yang menyerang tanaman kapas, serta cara penanggulangannya (Ndjurumbaha, Purwantara, \& Suwirmayanti, 2018). Dianni Yusuf pada tahun 2015 juga melakukan penelitian untuk pembangunan sistem pakar diagnosa hama penyakit pada tanaman jeruk. Sistem Pakar menjadi alternatif untuk membantu petani dalam mendiagnosa hama penyakit tanaman jeruk dengan menggunakan pengetahuan, fakta, dan teknik penalaran yang biasanya digunakan oleh Pakar di bidang Pertanian. Penggunaan metode forward chaining dalam mesin inferensi yang mengolah basis penget ahuan menjadi kesimpulan-kesimpulan yang diharapakan. Hasil luaran dari Aplikasi sistem pakar berupa berupa jenis hama penyakit tanaman jeruk dan solusi penanganan dari masing-masing hama penyakit berdasarkan gejala yang telah dimasukkan Pengguna Sistem (Yusuf, Hidayat, \& Ashari, 2015). Berdasarkan penjabaran penelitian sebelumnya maka penelitian ini akan mengambil secara khusus tentang penyakit yang dialami oleh tanaman kopi. Sistem pakar yang dihasilkan nantinya dapat memberikan hasil diagnosa yang efektif dan cara penanggulangannya. Sistem dibuat sangat mudah untuk digunakan oleh para petani ataupun Dinas Tanaman Pangan, Holtikultura, dan Perkebunan Pemerintah Provinsi Bali dan daerah, dimana pada antarmuka pengguna hanya perlu mencentang gejala penyakit yang dialami lalu pengguna akan langsung memperoleh hasil dan solusi penanganannya.

\section{METODE}

Proses pengumpulan data pada penelitian yang dilakukan bertujuan untuk menunjang data yang duperlukan. Metode pengumpulan data yang digunakan adalah sebagai berikut,

1. Observasi

Pengamatan secara langsung dilakukan pada tahapan ini. Pengamatan dilakukan pada objek penelitian secara langsung yaitu dengan pengamatan langsung terhadap tanaman kopi arabika di Subak Belantih.

2. Wawancara 
Tahapan wawancara dilakukan secara langsung kepada narasumber dan pihak-pihak terkait. Adapun narasumber yang diwawancarai adalah petani, Kepala Dinas dan Kepala Bagian di Dinas Tanaman Pangan, Holtikultura, dan Perkebunan Pemerintah Provinsi Bali.

3. Studi Literatur

Studi literature merupakan tahapan yang dilakukan dengan cara mengumpulkan sumber bacaan serta membaca dan merangkun informasi mengenai referensi penyakit-penyakit pada tanaman kopi arabika.

\section{A. Metode Waterfall}

Pada proses pengembangan sistem pakar dengan mengimplementasikan metode forward chaining ini menggnakan metode waterfall sebagai model pengembangan. Model air terjun (Waterfall) menyediakan pendekatan alur hidup perangkat lunak secara sekuensial atau terurut dimulai dari analisis, desain, pengodean, pengujian dan tahap pendukung (A.S \& Shalahuddin, 2018). Model ini kemudian dipilih untuk pengembangan karena sangat mudah untuk diaplikasikan dan struktur tahap pengembangan sistem jelas dan sebuah tahap dijalankan setelah tahap sebelumnya selesai dijalankan. Hal ini menyebabkan pelaksanaan tahap tidak tumpeng tindih. Berikut pada Gambar 1 merupakan gambaran dari model pengembangan waterfall.

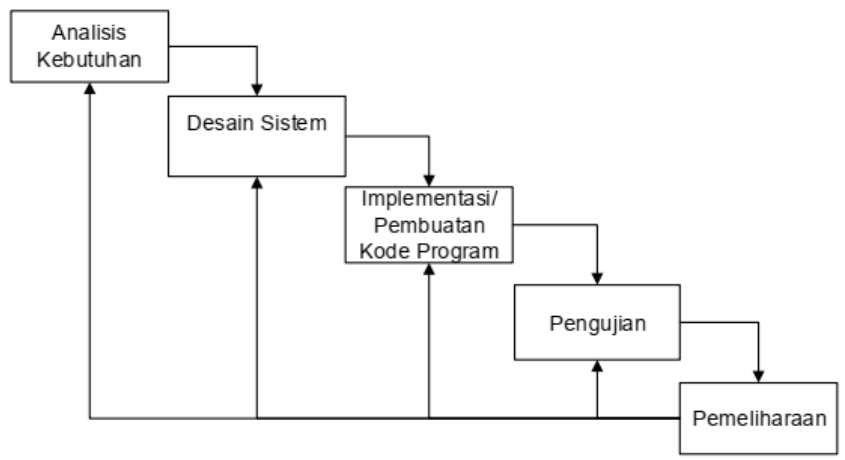

Gambar 1. Model Pengembangan Waterfall

\section{a. Analisis Kebutuhan}

Tahap analisis kebutuhan merupakan tahapan yang mengidentifikasi daftar kebutuhan interaksi pengguna dengan sistem. Hasil dari tahapan ini diperoleh dari data yang dikumpulkan dari objek penelitian yaitu penyakit tanaman kopi. Semua fakta dan data yang diperlukan dikumpulkan pada tahapan ini melalui observasi, wawancara pada pihak-pihak terkait dan juga studi literatur.

\section{b. Desain Sistem}

Tahap desain sistem merupakan tahapan yang berfokus pada desain sistem, arsitektur sistem dan desain antarmuka. Tahapan ini mentransformasi kebutuhan sistem dari tahapan analisis kebutuhan ke representasi desain agar dapat diimplementasikan ke dalam sebuah program pada tahapan selanjutnya. Desain sistem yang dibuat digambarkan dalam model DFD untuk mendesain fungsionalitas sistem dan ERD untuk model datanya.

\section{c. Implementasi/Pembuatan Kode Program}

Output pada tahapan desain kemudian ditransformasikan ke dalam kode program. Hasil dari tahapan ini adalah perangkat lunak yang sesuai dengan desain sistem yang telah dibuat. Pembuatan kode program dilakukan dengan menggunakan bahasa pemrograman PHP dan HTML.

\section{d. Pengujian}

Tahapan pengujian bertujuan untuk memastikan bahwa semua bagian sudah diuji dan secara fungsional semua unit sudah berjalan dengan baik. Melalui tahapan pengujian ini maka upaya meminimalisir eror terhadap program dapat dilakukan. Pada penelitian ini akan dilakukan pengujian blackbox testing untuk menguji fungsionalitas sistem apakah sudah berjalan dengan baik.

\section{e. Pemeliharaan}

Tahapan pemeliharaan dapat mengulangi proses pengembangan mulai dari analisis spesifikasi untuk perubahan sistem tetapi tidak membuat sistem baru. Perubahan kemungkinan terjadi karena ada 
kesalahan yang muncul dan tidak terdeteksi saat pengujian. Tahapan pemeliharaan pada penelitian ini tidak dilakukan.

\section{B. Metode Inferensi}

Inferensi merupakan sebuah proses untuk menghasilkan informasi dari fakta yang diketahui. Dalam pengembangan sistem pakar ini menggunakan metode inferensi runut maju (forward chaining). Dalam metode ini, data yang digunakan untuk menentukan aturan mana yang akan dijalankan, kemudian aturan tersebut dijalankan. Mungkin proses menambahkan data ke memori kerja. Proses diulang sampai ditemukan suatu hasil (Sutojo, Mulyanto, \& Suhartono, 2011).

Forward Chaining berarti menggunakan himpunan aturan kondisi-aksi. Dalam metode ini, data yang digunakan untuk menentukan aturan mana yang akan dijalankan, kemudian aturan tersebut dijalankan. Untuk memudahkan pemahaman mengenai metode forward chaining diberikan ilustrasi sebagai berikut :

\section{Aturan 1:}

Jika Premis 1

Dan Premis 2

Dan Premis 3

Maka Konklusi 1

Aturan 2:

Jika Premis 1

Dan Premis 3

Dan Premis 4

Maka Konklusi 2

Aturan 3 :

Jika Premis 2

Dan Premis 3

Dan Premis 5

Maka Konklusi 3

Aturan 4 :

Jika Premis 1

Dan Premis 4

Dan Premis 5

Dan Premis 6

Maka Konklusi 4

Penulusuran manju pada kasus ini adalah untuk mengetahuai apakah suatu fakta yang dialami oleh pengguna itu termasuk konklusi 1, konklusi 2, konklusi 3, atau konklusi 4 atau bahkan bukan salah satu dari konklusi tersebut, yang artinya sistem belum mampu mengambil kesimpulan karena keterbatasan aturan. Dalam penalaran ini, user diminta memasukan premis-premis yang dialami. Berdasarkan premispremis yang dipilih, maka sistem akan mencari aturan yang sesuai, sehingga akan diproleh konklusinya (Kusrini, 2008).

\section{HASIL DAN PEMBAHASAN}

\section{A. Basis Pengetahuan}

Dalam sistem pakar, basis pengetahuan mengandung pengetahuan yang diperlukan untuk memahami, memformulasikan dan menyelesaikan masalah. Basis pengetahuan disusun berdasarkan pengetahuan dari pakar (Kusrini, 2008). Dalam penelitian ini, pakar yang digunakan adalah narasumber dari Dinas Tanaman Pangan, Holtikultura dan Perkebunan yang menangani tanaman perkebunan. Adapun daftar gejala dan penyakit yang tersedia dalam basis pengetahuan dapat dilihat pada Tabel 1.

Tabel 1. Penyakit pada Kopi Arabika Kintamani

\begin{tabular}{ccl}
\hline No & Kode Penyakit & \multicolumn{1}{c}{ Nama Hama Dan Penyakit } \\
\hline 1 & P1 & Nematoda \\
2 & P2 & Hama Pengerek Buah \\
3 & P3 & Karat Daun \\
4 & P4 & Bercak Daun \\
\hline
\end{tabular}


Sedangkan untuk gejala yang muncul sebagai indicator untuk menentukan jenis penyakit yang menyerang pada tanaman kopi Arabika Kintamani dapat dilihat pada Tabel 3.2.

Tabel 2. Gejala yang Muncul pada Tanaman Kopi Arabika Kintamani

\begin{tabular}{ccl}
\hline No & Kode Gejala & \\
\hline 1 & G1 & Daun mudah gugur \\
2 & G2 & Tanaman menjadi gundul \\
3 & G3 & Daun menguning \\
4 & G4 & Tanaman kerdil \\
5 & G5 & Cabang samping jarang tumbuh \\
6 & G6 & Akar membusuk \\
7 & G7 & Terdapat lubang pada ujung buah \\
8 & G8 & Gugur pada buah muda \\
9 & G9 & Cacat pada buah tua \\
10 & G10 & Daun terdapat bercak \\
11 & G11 & Bercak berwarna kuning \\
12 & G12 & Dibalik daun terdapat serbuk berwarna jingga cerah \\
13 & G13 & Bercak yang sudah tua berwarna coklat \\
14 & G14 & Bercak berwarna coklat kemerahan atau coklat tua \\
15 & G15 & Bercak dikelilingi halo (lingkaran) berwarna kuning \\
16 & G16 & Terdapat bercak pada buah \\
17 & G17 & Kulit buah terkena bercak menjadi mengeras \\
\hline
\end{tabular}

Tabel 3 menunjukan hubungan antara gejala dan penyakit yang menyerang tanaman Kopi Arabika Kintamani.

Tabel 3. Daftar Hubungan Gejala dan Penyakit Tanaman Kopi Arabika

\begin{tabular}{|c|c|}
\hline Jenis Penyakit & Gejala \\
\hline \multirow[t]{6}{*}{ P1 (Nematoda) } & G1 : Daun mudah gugur \\
\hline & G2 : Tanaman menjadi gundul \\
\hline & G3 : Daun menguning \\
\hline & G4 : Tanaman kerdil \\
\hline & G5 :Cabang samping jarang tumbuh \\
\hline & G6 : Akar membusuk \\
\hline P2 (Hama Pengerek & G7 : Terdapat lubang pada ujung buah \\
\hline \multirow[t]{2}{*}{ Buah) } & G8 : Gugur pada buah muda \\
\hline & G9: Cacat pada buah tua \\
\hline \multirow[t]{5}{*}{ P3 (Karat Daun) } & G1 : Daun mudah gugur \\
\hline & G2 : Tanaman menjadi gundul \\
\hline & G10 : Daun terdapat bercak \\
\hline & G11 : Bercak berwarna kuning \\
\hline & G12 : Dibalik daun terdapat serbuk berwarna jingga cerah \\
\hline \multirow[t]{6}{*}{ P4 (Bercak Daun) } & G10 : Daun terdapat bercak \\
\hline & G13 : Bercak yang sudah tua berwarna coklat \\
\hline & G14 : Bercak berwarna coklat kemerahan atau coklat tua \\
\hline & G15 : BErcak dikelilingi halo (lingkaran) berwarna kuning \\
\hline & G16 : Terdapat bercak pada buah \\
\hline & G17 : Kulit buah terkena bercak menjadi mengeras \\
\hline
\end{tabular}

\section{B. Metode Inferensi}

Tabel keputusan digunakan sebagai dasar untuk membuat pohon keputusan dan kaidah produksi. Tabel Keputusan untuk penelitian ini dapat dilihat pada Tabel 4.

Tabel 4. Table Keputusan

\begin{tabular}{ccccc}
\hline Gejala & P1 & P2 & P3 & P4 \\
\hline G1 & & & & \\
G2 & & & & \\
G3 & & &
\end{tabular}




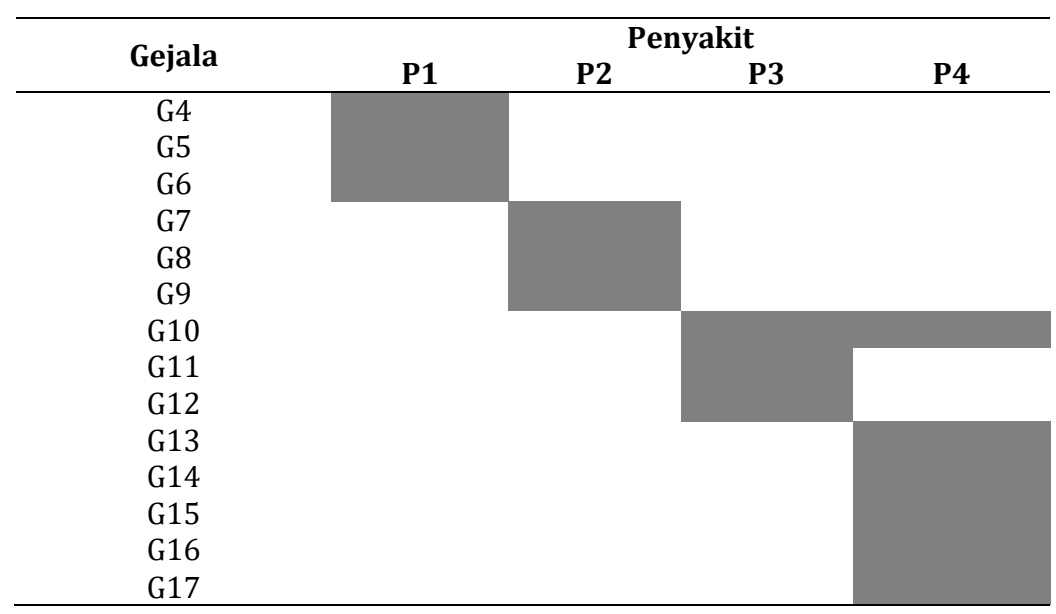

Pohon Keputusan merupakan gambaran analisis pemecahan masalah berdasarkan aturan-aturan yang ada pada basis pengetahuan. Pohon keputusan dimulai dari gejala atau fakta kemudia mengarah ke sebuah keputusan. Pohon keputusan pada sistem pakar diagnosa penyakit kopi Arabika dimulai dari G1 kemudian dilanjutkan oleh gejala lainnya yang kemudian mengarah pada suatu kesimpulan. Terdapat dua kesimpulan yang didapat dalam pohon keputusan tersebut yaitu sebuah penyakit yang dilambangkan dengan P dan TH (tidak hasil), didapatkan hasil TH dikarenakan gejala-gejala tersebut tidak memenuhi untuk suatu penyakit. Pohon keputusan tersebut dapat dilihat pada Gambar 2 sebagai berikut.

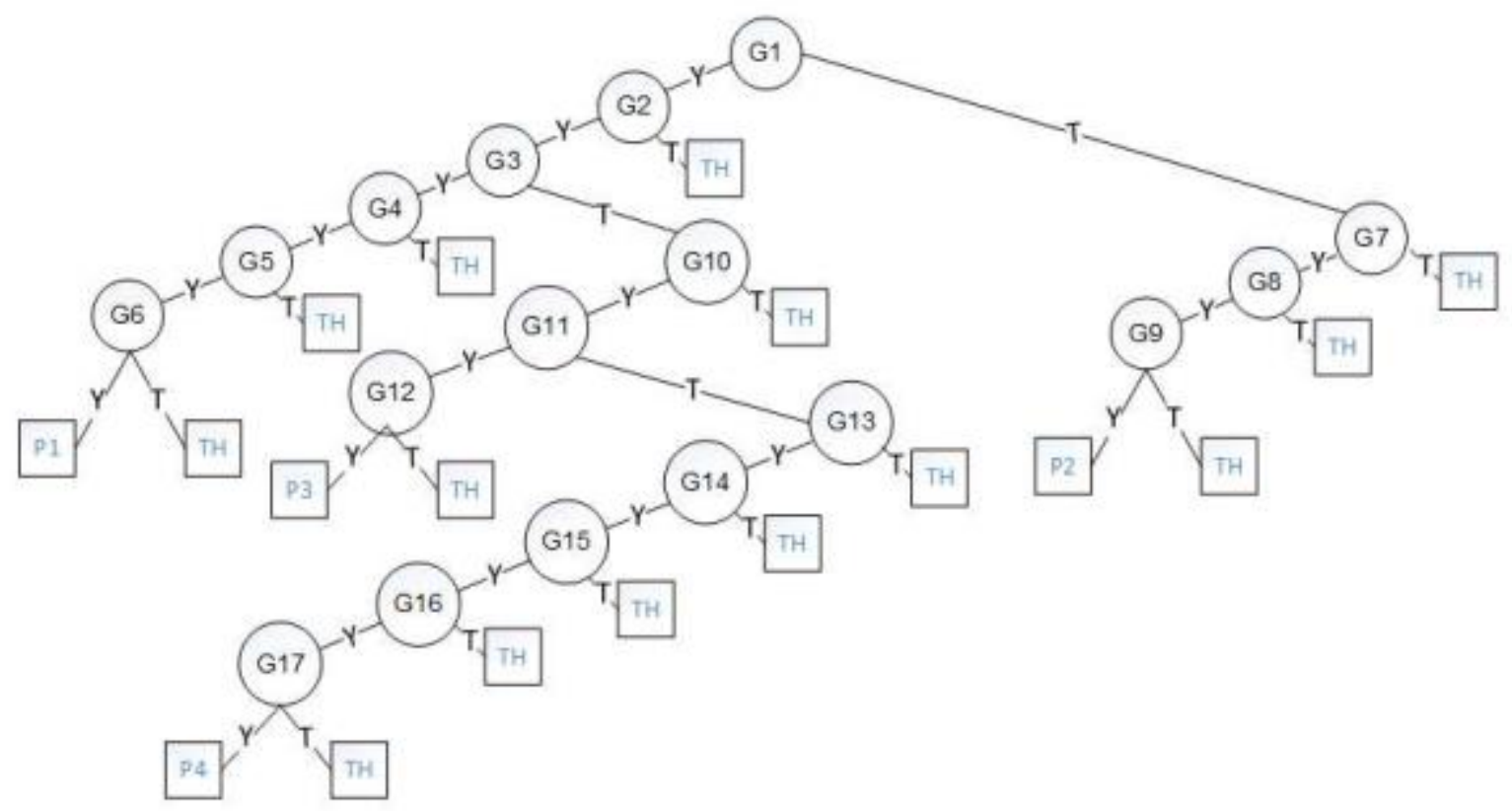

Gambar 2. Pohon Keputusan

Berdasarkan pohon keputusan dihasilkan kaidah produksi untuk merepresentasikan aturan (rule). Aturan gejala dari penyakit kopi Arabika di Kintamani dapat dilihat pada Tabel 5.

Tabel 5. Aturan Gejala dan Penyakit

\begin{tabular}{clllll}
\hline No & \multicolumn{5}{c}{ Aturan Gejala Penyakit } \\
\hline 1 & IF Daun mudah gugur (G1) AND Tanaman menjadi gundul (G2) AND Daun menguning (G3) AND Tanaman \\
& kerdil (G4) AND Cabang samping jarang tumbuh $\quad$ (G5) AND akar membusuk (G6) THEN \\
& $\begin{array}{l}\text { Nematoda (P1) } \\
\text { IF Terdapat lubang pada ujung buah (G7) AND Gugur pada buah muda (G8) AND Cacat pada buah tua (G9) } \\
\text { THEN Hama Pengerek Buah (P2) }\end{array}$ \\
\hline
\end{tabular}




\begin{tabular}{|c|c|}
\hline No & Aturan Gejala Penyakit \\
\hline 3 & $\begin{array}{l}\text { IF Daun mudah gugur (G1) AND Tanaman menjadi gundul (G2) Daun terdapat bercak (G10) AND Bercak } \\
\text { berwarna kuning (G11) AND Dibalik daun terdapat serbuk berwarna jingga cerah (G12) THEN Karat Daun } \\
\text { (P3) }\end{array}$ \\
\hline 4 & $\begin{array}{l}\text { IF Daun terdapat bercak (G10) AND Bercak yang sudah tua berwarna coklat (G13) AND Bercak berwarna } \\
\text { coklat kemerahan atau coklat tua (G14) AND Bercak dikelilingi halo (lingkaran) berwarna kuning (G15) AND } \\
\text { Terdapat bercak pada buah (G16) AND Kulit buah terkena bercak menjadi mengeras (G17) THEN Bercak } \\
\text { Daun (P4) }\end{array}$ \\
\hline
\end{tabular}

\section{Implementasi Sistem}

Sistem pakar untuk mendiagnosis penyakit tanaman kopi dibangun berbasis web dan basis data yang digunakan adalah MySQL dan PhpMyAdmin. Sistem yang dihasilkan dapat secara langsung digunakan untuk mendiagnosis penyakit pada tanaman kopi. Pengguna memilih gejala yang terjadi pada tanaman kopinya dan mengisi checkbox pilih gelaja lalu memproses diagnosis seperti pada Gambar 3 .

Sistem juga menyediakan halaman menu untuk menginputkan data penyakit. Selain menginputkan pada halaman ini, pengguna dapat mengelola data penyakit seperti merubah dan menghapus. Halaman untuk data penyakit dapat dilihat pada Gambar 4. Selain untuk data penyakit, pengguna juga dapat mengelola data gejala yang dialami oleh Tanaman Kopi Arabika Kintamani. Halaman data gejala dapat dilihat pada Gambar 5.

Sistem pakar ini dilengkapi dengan Menu Mapping Rules yang bertujuan untuk menambahkan gejala pada suatu penyakit sesuai denga rules yang ada. Rules yang ada bersifat baku. Tampilan halaman untuk menu mapping rules dapat dilihat pada Gambar 6.
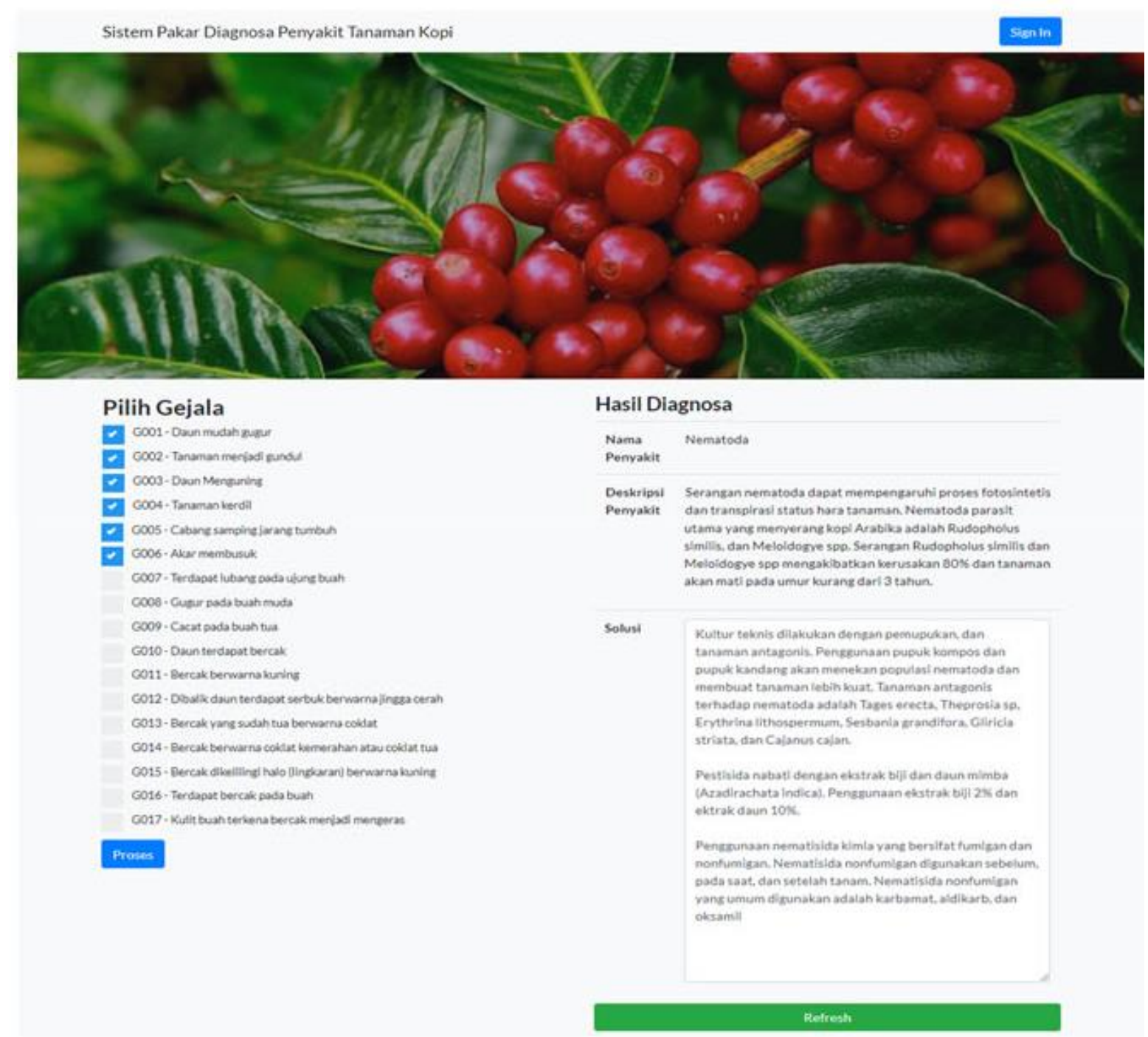

Gambar 3 Tampilan Halaman Utama Sistem 


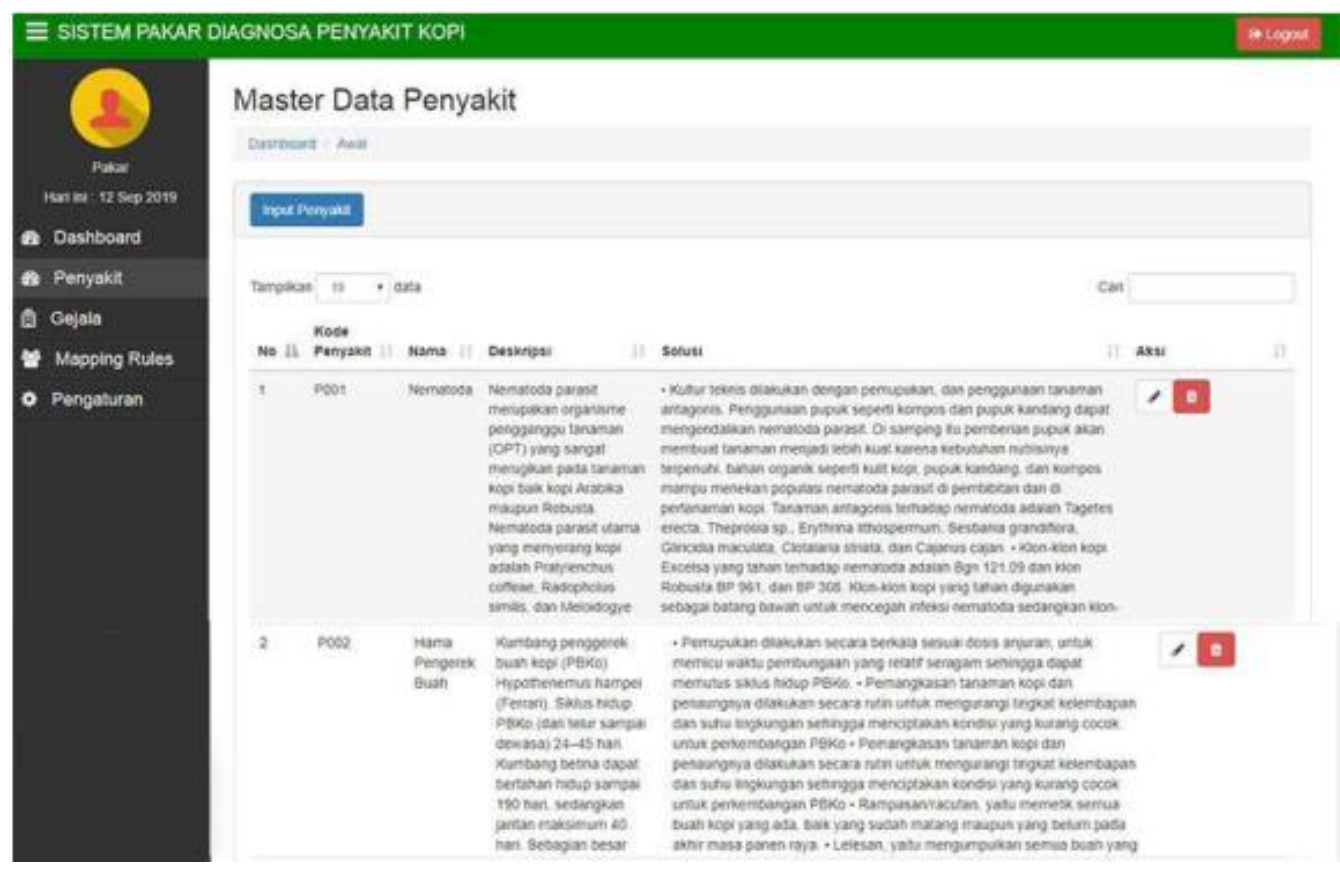

Gambar 4 Tampilan Data Penyakit

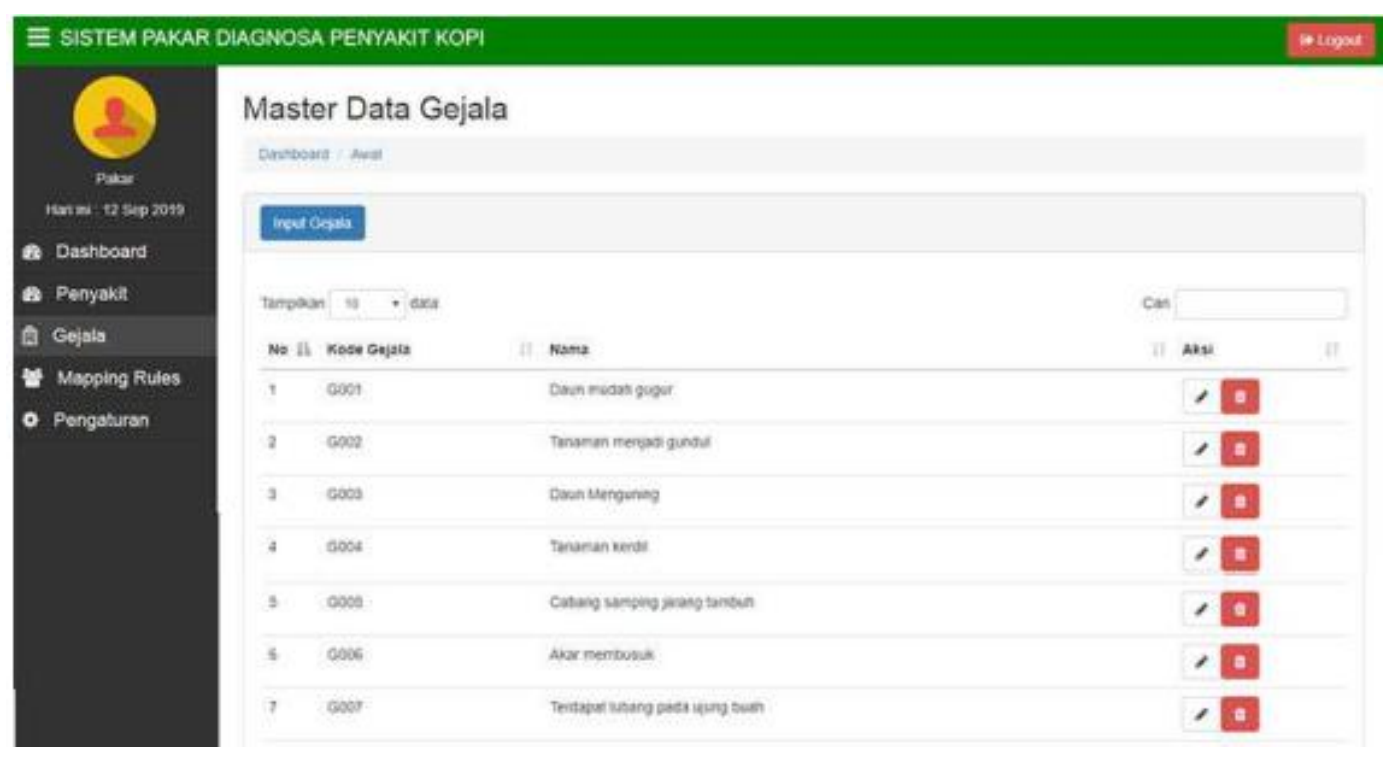

Gambar 5 Tampilan Data Gejala 


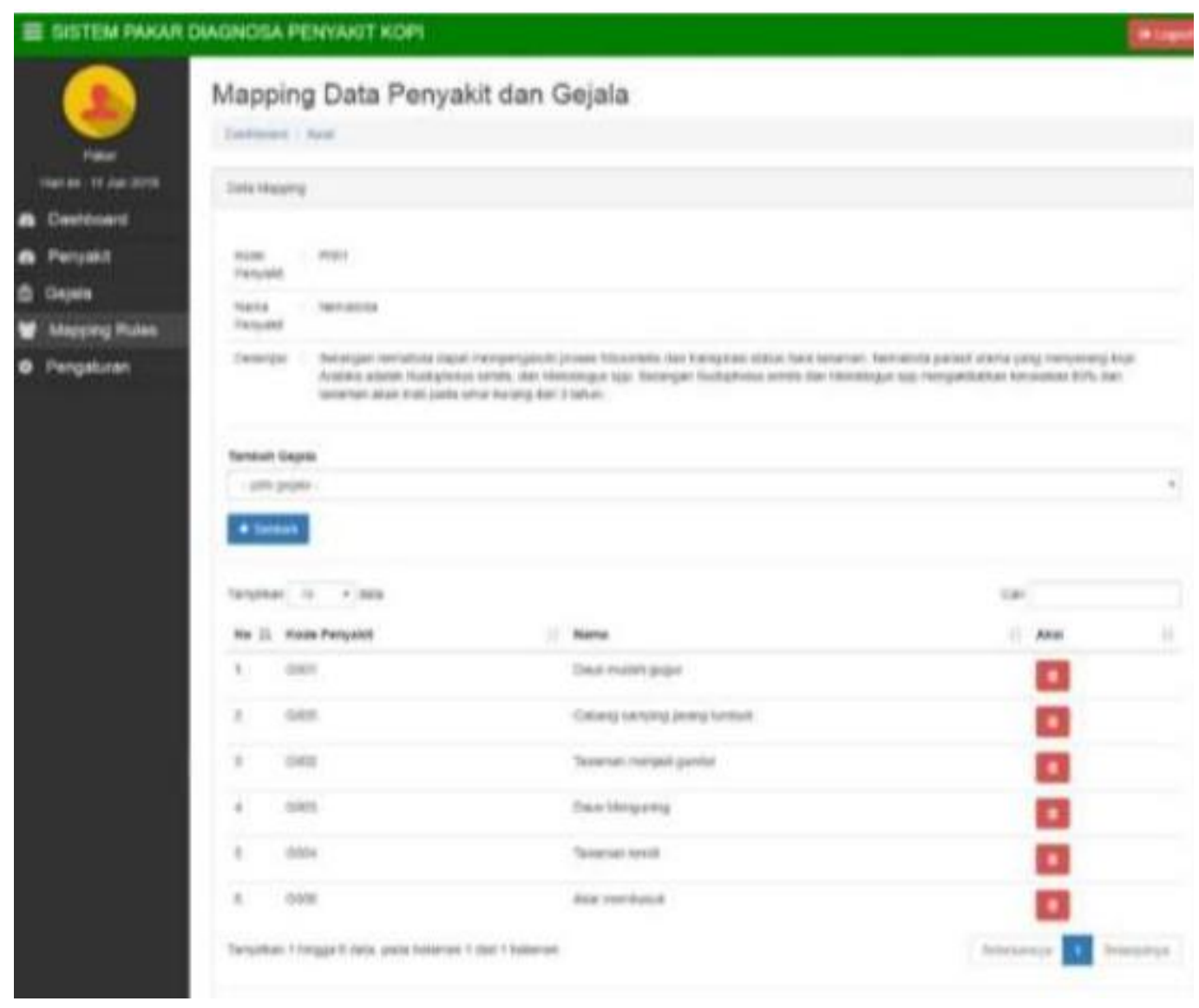

Gambar 6. Tampilan Mapping Data Penyakit dan Gejala

\section{Pengujian Sistem}

Pengujian sistem dilakukan dengan metode blackbox testing. Dimana metode ini merupakan metode yang bertujuan untuk menguji apakah fungsi-fungsi yang ada dapat berjalan sesuai dengan yang diharapkan. Hasil pengujian yang diperoleh berdasarkan rencana pengujian yang telah disusun menyatakan bahwa semua fungsi didalam Sistem Pakar Diagnosis Penyakit Tanaman Kopi Arabika berjalan dengan baik dan sesuai dengan yang diharapkan.

\section{SIMPULAN DAN SARAN}

Adapun simpulan yang dapat ditarik dari penelitian ini adalah sebagai berikut.

1. Sistem pakar diagnosa penyakit tanaman kopi Arabika dapat menghasilkan diagnosa jenis penyakit tanaman kopi Arabika yang sesuai berdasarkan aturan-aturan yang telah dibuat dengan menerapkan metode forward chaining.

2. Sistem pakar yang telah dibuat dapat digunakan untuk mendiagnosa jenis penyakit tanaman kopi Arabika berdasarkan gejala yang terlihat dan menghasilkan solusi tindakan berdasarkan hasil diagnosa penyakitnya.

3. Pengujian sistem menggunakan metode pengujian black box testing dan didapatkan hasil sesuai untuk semua fungsi yang diharapkan.

\section{Daftar Pustaka}

A.S, R., \& Shalahuddin, M. (2018). Rekayasa Perangkat Lunak. Bandung: Informatika Bandung. Kusrini. (2008). Sistem Pakar. In Aplikasi Sistem Pakar (I, pp. 8-10). Yogyakarta: Andi.

Maridelana, V. P., Hariyati, Y., \& Kuntadi, E. B. (2014). FUNGSI KEUNTUNGAN USAHATANI KOPI RAKYAT DI DESA BELANTIH KECAMATAN KINTAMANI KABUPATEN BANGLI. Berkala Ilmiah Pertanian, 1(3), 4752.

Ndjurumbaha, E. U. ., Purwantara, I. M. A., \& Suwirmayanti, N. L. G. P. (2018). SISTEM PAKAR DIAGNOSA PENTAKIT TANAMAN KAPAS MENGGUNAKAN METODE DECISION TREE BERBASIS ANDROID. STIKOM 
Bali.

Sutojo, T., Mulyanto, E., \& Suhartono, V. (2011). Sistem Pakar. In Kecerdasan Buatan (I, pp. 160-169). Yogyakarta: Andi.

Yoga Priantara, I., Mulyani, S., \& Satriawan, I. (2017). Analisis Nilai Tambah Pengolahan Kopi Arabika Kintamani Bangli. Jurnal Rekayasa Dan Manajemen Agroindustri, 4(4), 33 - 42.

Yusuf, D., Hidayat, A., \& Ashari, B. (2015). Agroinformatika Sistem Pakar Diagnosa Hama Penyakit dan Penanganan Pada Tanaman Jeruk Berbasis Web di Purwoharjo, 6-10. 